\title{
A new species of the millipede genus Cryptocorypha Attems, 1907, from Vanuatu, Melanesia, southwestern Pacific (Diplopoda: Polydesmida: Pyrgodesmidae)
}

\author{
Новый вид дипмопод рода Cryptocorypha Attems, 1907, \\ из Вануату (Меманезия, юго-запад Тихого океана) \\ (Diplopoda: Polydesmida: Pyrgodesmidae)
}

\author{
S.I. Golovatch ${ }^{1}$, J.-J. Geoffroy ${ }^{2}$, D. VandenSpiegel ${ }^{3}$ \\ С.И. Головач ${ }^{1}$, Ж.-ЖК. ЖКоффруа ${ }^{2}$, А. ВанденШпигель ${ }^{3}$
}

\footnotetext{
${ }^{1}$ Institute for Problems of Ecology and Evolution, Russian Academy of Sciences, Leninsky prospekt 33, Moscow 119071 Russia.

${ }^{1}$ Институт проблем экологии и эволюции РАН, Ленинский проспект, 33, Москва 119071 Россия.

${ }^{2}$ Muséum national d'Histoire naturelle, Département Ecologie \& Gestion de la Biodiversité, UMR 7204 CESCO, 4, avenue du Petit Château, F-91800 Brunoy, France.

${ }^{2}$ Национальный музей естественной истории, Брюнуа, Франция.

${ }^{3}$ Musée Royal de l'Afrique centrale, B-3080 Tervuren, Belgium.

${ }^{3}$ Королевский музей Центральной Африки, Тервурен, Бельгия.
}

KEY WORDS: Diplopoda, Pyrgodesmidae, Cryptocorypha, new species, Vanuatu. КЛЮЧЕВЫЕ СЛОВА: Diplopoda, Pyrgodesmidae, Cryptocorypha, новый вид, Вануату.

ABSTRACT. A new species of the rather large, basically tropical/subtropical Asian genus Cryptocorypha is described from the Espiritu Santo Island, Vanuatu: $C$. chernovi sp.n. This is the $12^{\text {th }}$ species in the genus and the second member of Pyrgodesmidae presumably endemic to Vanuatu. It differs from all sufficiently well described congeners but $C$. stylopus Attems, 1907, from Java, Indonesia, in having 19 body segments in the $\sigma^{\top}$, from the remaining congeners by the narrower paraterga, combined with certain details of gonopod structure.

РЕЗЮМЕ. С острова Эспириту-Санто (Вануату) описан новый вид довольно большого, в основном тропического или субтропического азиатского рода Cryptocorypha: C. chernovi sp.n. Это 12-й вид в составе рода и второй представитель Pyrgodesmidae, видимо, эндемичного для Вануату. Он отличается от всех достаточно подробно описанных видов рода, кроме C. stylopus Attems, 1907, с острова Явы (Индонезия), наличием 19 сегментов тела у $\sigma^{7}$, от прочих видов более узкими паратергитами в сочетании с некоторыми деталями строения гоноподов.

\section{Introduction}

The basically pantropical family Pyrgodesmidae is amongst the largest in the class Diplopoda, at the present counting nearly 180 genera alone [e.g. Hoffman, 1980]. The recently reviewed genus Cryptocorypha Attems, 1907, currently encompasses 11 species [Golovatch et al., 2011]: C. stylopus Attems, 1907 (the type species) and C. leia Chamberlin, 1945, both from Java, Indonesia; C. tobana Chamberlin, 1945, from Sumatra, Indonesia; C. ornata (Attems, 1938), nearly pantropical, especially characteristic of remote archipelagos; $C$. hoffmani Golovatch, Semenyuk, VandenSpiegel et Anichkin, 2011, from southern Vietnam; C. areata (Carl, 1932) and C. tuberculata (Carl, 1932), both from southern India; C. kandyana (Carl, 1932), from Sri Lanka; C. spinicoronata (Zhang et Li, 1981), from southern China; C. japonica (Miyosi, 1957) and C. kumamotensis (Murakami, 1966), from southern Honshu and Kyushu, Japan, respectively.

Because some of the species are too poorly known, no key to Cryptocorypha spp. can be attempted yet [Golovatch et al., 2011]. Thus, we still do not know even the number of body segments in the $\sigma^{7}$ of both $C$. tobana and C. leia. Most of the species of Cryptocorypha show 20 segments in adult $\sigma^{7} \sigma^{7}$ and 90 , but in $C$. stylopus and the new species described herein the $\sigma^{7}$ has 19 segments, as opposed to 20 in the + . Considering that $C$. leia also stems from Java, relevant type material of this and several other species must be revised before a useful key could be compiled.

The present note puts on record a new congener from Vanuatu, the second species of Pyrgodesmidae following Lobiferodesmus vanuatu Golovatch, Geoffroy, Mauriès et VandenSpiegel, 2008, to be reported from the Espiritu Santo Island [Golovatch et al., 2008]. This island appears to support at least another two pyrgodesmids, regrettably both represented in the avail- 


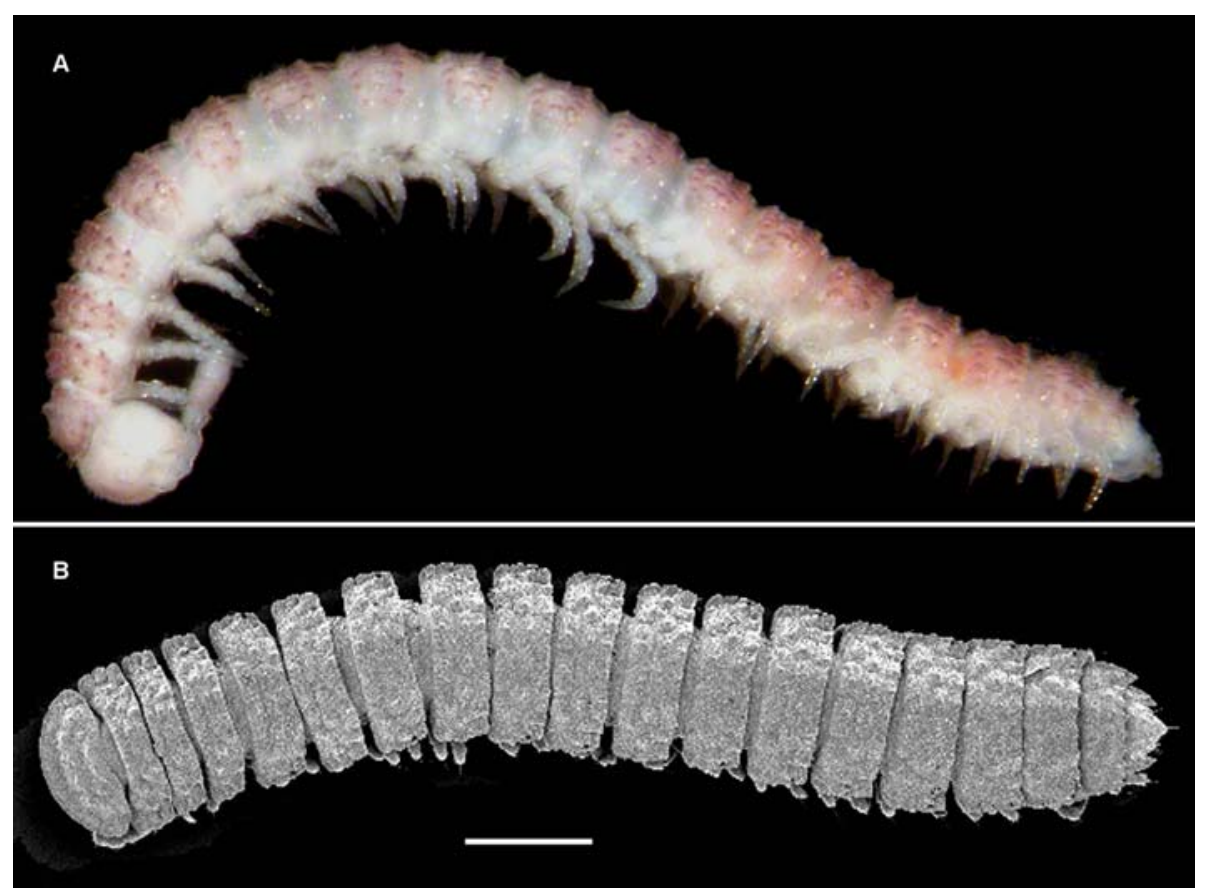

Fig. 1. Cryptocorypha chernovi sp.n., + paratype: $\mathrm{A}-\mathrm{B}-$ habitus, lateral and dorsal views, respectively. Photographed not to scale (A); scale bar: $0.5 \mathrm{~mm}$ (B).

Рис. 1. Cryptocorypha chernovi sp.n., паратип +: А-B - внешний вид, соответственно сбоку и сверху. Сфотографировано без масштаба (A); масштаб 0,5 мм (B).

able samples solely by females or juveniles. So their identities are bound to remain dubious pending males finally become accessed for study.

Like nearly all millipede material from Vanuatu, the type series of the new species has been taken during the famous SANTO 2006 expedition held by the Muséum national d'Histoire naturelle, Paris, France [Bouchet et al., 2009, 2011, 2012].

\section{Material and methods}

Material was collected in 2006 during the SANTO 2006 Global Biodiversity Survey which focused on sampling the biota of the Espiritu Santo Island, Vanuatu. Millipedes as representing land fauna were taken by Group "Karst" which included Louis Deharveng, Anne Bedos (MNHN, Paris, France), Cahyo Rahmadi (Museum Zoologicum Bogoriense, Cibinong, Java, Indonesia), Josiane Lips (Villeurbanne, France) and several other persons, as well as by Group "Forest". Hand collection was combined with Berlese extractions, the latter techniques having allowed for the bulk of smaller millipedes to be taken, including the pyrgodesmids.

The holotype and most of the paratypes are housed in the Muséum national d'Histoire naturelle (MNHN), Paris, France, with only two paratypes shared with the collection of the Zoological Museum, State University of Moscow (ZMUM), Moscow, Russia.

SEM micrographs were taken using a JEOL JSM6480LV scanning electron microscope. After examina- tion, SEM material was removed from stubs and returned to alcohol, now in MNHN.

\section{Taxonomic part}

\section{Cryptocorypha chernovi sp.n.}

Figs 1-3.

HOLOTYPE $0^{7}$ (MNHN JC 347), Vanuatu, Espiritu Santo Island, Rotal, near Rotal hole, $167.0584667^{\circ} \mathrm{E}, 15.2528^{\circ} \mathrm{S}, 250 \mathrm{~m}$ a.s.l., forest, litter, Berlese extraction, 9.09.2006, leg. C. Rahmadi (SK06-09/19, Rotal 3L).

PARATYPES: 1 O, 1 juv. (MNHN JC 347), same locality, together with holotype; 1 (SEM), $1 \sigma^{7}, 1$ juv. (ZMUM), same data, 9.09.2006 (SK06-09/15); $1 \sigma^{7}$ (MNHN JC 347), Espiritu Santo Island, Boutmas, near the entrance to Fapon Cave, $166.9648833^{\circ} \mathrm{E}, 15.33101667^{\circ} \mathrm{S}, 380 \mathrm{~m}$ a.s.1., forest, litter, Berlese extraction, 8.09.2006, leg. L. Deharveng \& C. Rahmadi (SK06-08/ 24); 2 juv. (MNHN JC 347), Malo Island off Espiritu Santo, Avorani, $167.12875^{\circ} \mathrm{E}, 15.70615^{\circ} \mathrm{S}, 110 \mathrm{~m}$ a.s.1., forest, litter, Berlese extraction, 15.09.2006, leg. L. Deharveng \& A. Bedos (SK06-15/04, Malo 1L).

NAME. Dedicated to the memory of Academician Yuri Ivanovich Chernov, an outstanding Russian ecologist and biogeographer, deceased in May 2012, on the occasion of his $80^{\text {th }}$ birthday which is due in January 2014.

DIAGNOSIS. Differs from all sufficiently well described congeners except C. stylops [see Attems, 1907] by the presence of only 19 body segments in the $\sigma^{7}$, from $C$. stylops and the remaining species of the genus both by narrower paraterga and the quite complex go- 

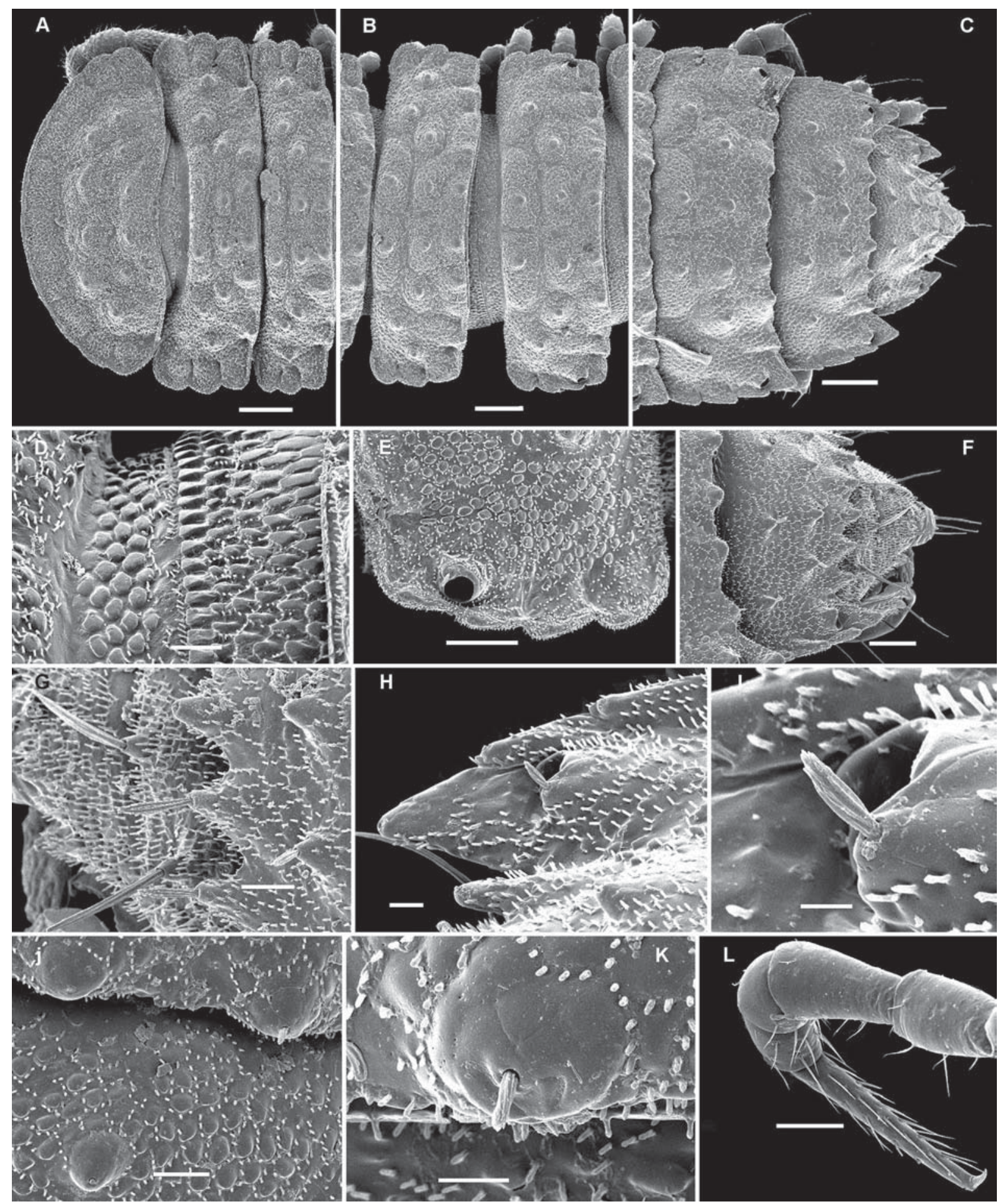

Fig. 2. Cryptocorypha chernovi sp.n., 9 paratype: A - anterior body part, dorsal view; B - midbody segments, dorsal view; C, F caudal body part, dorsal and dorsolateral views, respectively; D - tegument texture in the region of a stricture between pro- and metazona, subdorsal view; E - poriferous midbody paratergum, dorsal view; $\mathrm{G}$ - metatergal tubercles and setae of two different types in segment 19 , dorsal view; H, I - caudal half of paratergum 19, its ozopore and tergal setae of two different types, dorsal view; J, K - metatergal tubercles and a short tergal seta, dorsal view; L - midbody leg. Scale bars: 0.1 (A-C), 0.05 (E, F, L), 0.02 (D, G. H, J) \& 0.01 mm (I, K).

Pис. 2. Cryptocorypha chernovi sp.n., паратип : А - передняя часть тела, сверху; В - среднетуловищные сегменты, сверху; C - задняя часть тела, сверху; D - текстура покровов в районе шва между про- и метазонитами, почти сверху; Е несущий озопору среднетуловищный паратергит, сверху; $\mathrm{G}$ - метатергальные бугорки и щетинки двух типов на сегменте 19 , сверху; H, I - задняя часть паратергита 19, его озопора и щетинки двух типов на сегменте 19, сверху; J, K - метатергальные бугорки и короткая щетинка сверху; L — среднетуловищная нога. Масштаб: 0,1 (A-C), 0,05 (E, F, L), 0,02 (D, G. H, J) и 0,01 мм (I, K). 

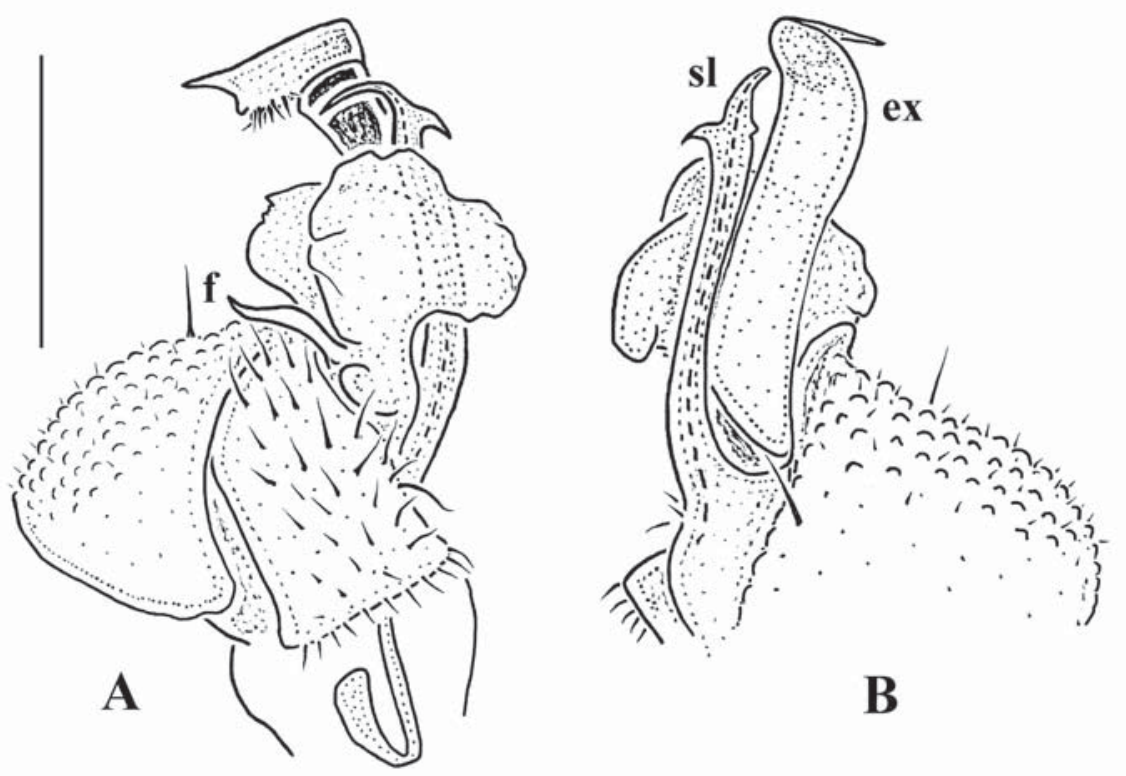
$\mathrm{mm}$.

Fig. 3. Cryptocorypha chernovi sp.n., $\mathrm{O}^{7}$ paratype: A \& B — right gonopod, mesal and sublateral views, respectively. Scale bar: 0.1 0,1 мм.

nopods, including the rather small coxae, the larger and longer exomere (ex) which is curved only subapically, a bifid solenomere (sl), and the presence of a parabasal flagelloid outgrowth (f) on the medial face of the telopodite.

DESCRIPTION. Length ca $4.5-5.0 \mathrm{~mm}$, width of midbody segments $0.35-0.4$ and $0.55-0.6 \mathrm{~mm}$ on midbody pro- and metazona, respectively $\left(\sigma^{7}\right)$. Holotype ca $5.0 \mathrm{~mm}$ long, 0.35 and $0.55 \mathrm{~mm}$ wide on midbody pro- and metazona, respectively. Length of adult $90+\mathrm{ca}$ $7-8 \mathrm{~mm}$, width of midbody pro- and metazona 0.45 0.7 and $0.7-1.0 \mathrm{~mm}$, respectively. Coloration from uniformly light pinkish (live or freshly fixed material), especially so due to metaterga (Fig. 1A), to entirely pallid, fully faded in alcohol.

Body relatively slender due to rather narrow paraterga (Figs 1, 2A-C), with $19\left(\sigma^{7}\right)$ or $20(+)$ segments. In width, head $<<$ collum $<$ segment $3 \leq 4<2<5=$ $15(16)$, thereafter body rapidly tapering towards telson (Figs 1B, 2C). Head ovoid, slightly transverse, densely setose in clypeolabral region, smooth above antennal sockets. Interantennal isthmus about twice as large as length of antennomere 1. Antennomere 6 largest, particularly large groups of apicodorsal sensilla on antennomeres 5 and 6 absent.

Collum (Fig. 2A) completely covering head from above, fore margin with $6+6$ equal, evident, only very faintly incised lobulations; middle and caudal parts with three transverse, arched, rather distinct rows of low bosses, each of these surmounted by a minute knob (= insertion point of an abraded seta). Paraterga lying at about midbody height, moderately sloping down at about $20-25^{\circ}$ (Figs 1, 2A-C). Dorsum clearly convex, paraterga regularly continuing its outline. Tegument encrusted with a microspiculate cerategument, dull, beset with microvilli (Figs $2 \mathrm{G}-\mathrm{K}$ ). Prozona and stricture between pro- and metazona very delicately alveolate (Fig. 2D). Metaterga with non-differentiated tuberculations, like much of collum with three transverse and distinct rows of usually transversely oblong, polygonal to rounded, low bosses, each of them often also surmounted by a minute knob (Figs 1B, 2A-C, F-K). Tergal setae largely abraded, retained ones inconspicuous, usually very short and ribbed longitudinally (Figs $2 \mathrm{G}-\mathrm{K}$ ), only in caudalmost row on penultimate metatergum considerably elongate (Fig. 2G, H). Postcollum paraterga thin and rather indistinctly lobulated laterally (Figs 1B, 2A-C, E, H), with three lobulations in all poreless segments, with four lobulations in all porebearing ones; front marginals absent, only $\mathrm{Cm} 2$ and/or $\mathrm{Cm} 3$ evident among caudal marginals. Ozopore formula normal: 5, 7, 9, 10, 12, 13,15-18(19), all pores being very small, round, discernible dorsally at base of $3^{\text {rd }}$ lobulation (Figs $\left.2 \mathrm{~A}-\mathrm{C}, \mathrm{E}, \mathrm{H}\right)$. Limbus microcrenulate, each crenulation being extremely finely denticulate/fringed (Fig. 2D). Epiproct readily visible from above, not hidden under segment $18\left(\sigma^{7}\right)$ or $19(+)$ (Figs 2C, F). Hypoproct subtriangular, caudal edge with $1+1$ strong, widely separated setae on knobs. Sterna not particularly narrow, about as broad as coxa. Legs (Fig. 2L) equally short and slightly enlarged in both sexes, tarsi longest, last tibia of both sexes with an evident distodorsal tubercle (Fig. 2C). Epigynal ridge behind $q$ coxae 2 low and inconspicuous.

Gonopods (Fig. 3) taking up most of ventral surface of segment 7, almost reaching bases of paraterga from below. Coxae voluminous, but rather low, transverse, each with two strong setae, microgranulate and mi- 
crosetose on lateral surface; cannulae as usual; gonocoel not very prominent, leaving most of telopodites exposed. Each telopodite represented by a relatively stout, strongly setose, prefemoral part which is about half the length of acropodite. Solenomere (sl) long, slender, rather simple, branching off parabasally, clearly bifid, both apical branchlets being pointed and only slightly unequal. Exomere (ex) a strong, thicker and higher branch curved laterad only near a spiniform apex, fringed/spinulate dorso-subapically. A marked, subflagelliform outgrowth (f) near end of prefemoral part on mesal face.

REMARKS. The patronym honours the late Academician Chernov, who not only collected extensively in the southern Pacific by himself, but also showed, among many other things, that many of the remote archipelagos in the region appear to be populated by relatively primitive members of their respective lineages, including pantropical "tramp" species [Chernov, 1982].

ACKNOWLEDGEMENTS. We are most grateful to Louis Deharveng and Anne Bedos (both MNHN) for having rendered us their collections of Diplopoda for study. In addition, they very helpfully took the colour picture (Fig. 1A). The material was collected during the SANTO 2006 Expedition organized by the MNHN, Pro Natura International (PNI), and the Institut de Recherche pour le Développement (IRD), which operated under a permit granted to P. Bouchet by the Environment Unit of the Government of Vanuatu. Special thanks go to the MNHN administration for financing the first author's stay in Paris in March and April 2013.

\section{References}

Attems C. 1907. Javanische Myriopoden gesammelt von Direktor K. Kraepelin im Jahre 1903 // Mitteilungen aus dem Naturhistorischen Museum Hamburg. Bd.24. S.77-122.

Bouchet P., Le Guyader H., Pascal O. 2009. The SANTO 2006 Global Biodiversity Survey: An attempt to reconcile the pace of taxonomy and conservation // Zoosystema. Vol.31. No.3. P.401-406.

Bouchet P., Le Guyader H., Pascal O. (eds.). 2011. The Natural History of Santo // Patrimoines Naturels. Paris: Muséum national d'Histoire naturelle. No.70. $572 \mathrm{pp}$.

Bouchet P., Le Guyader H., Pascal O. 2012. The altruism of biodiversity exploration expeditions // Zoosystema. Vol.34. No.2. P.193-202.

Chernov Y.I. 1982. [On the pathways of and sources for the formation of the fauna of Oceania's smaller islands] // Zhurnal Obshchey Biologii. T.43. No.1. P.35-47 [in Russian].

Golovatch S.I., Geoffroy J.-J, Mauriès J.-P., VandenSpiegel D. 2008. The first, new species of the millipede family Pyrgodesmidae to be recorded in Vanuatu, Melanesia, southwestern Pacific (Diplopoda: Polydesmida) // Arthropoda Selecta. Vol.17. Nos 3/4. P.145-151.

Golovatch S.I., Semenyuk I.I., VandenSpiegel D., Anichkin A.E. 2011. Three new species of the millipede family Pyrgodesmidae from Nam Cat Tien National Park, southern Vietnam (Diplopoda: Polydesmida)// Arthropoda Selecta. Vol.20. No.1. P.1-9.

Hoffman R.L. 1980. Classification of the Diplopoda. Genève: Muséum d'histoire naturelle. 237 pp.

Responsible editor K.G. Mikhailov 